\begin{tabular}{|l|l|l||}
\hline \multicolumn{2}{|c|}{ PublisherInfo } \\
\hline \hline PublisherName & $:$ & BioMed Central \\
\hline \hline PublisherLocation & $:$ & London \\
\hline \hline PublisherImprintName & $:$ & BioMed Central \\
\hline \hline
\end{tabular}

\title{
Mining myelination
}

\begin{tabular}{|l|l|l||}
\hline \multicolumn{2}{|c|}{ ArticleInfo } \\
\hline \hline ArticleID & $:$ & 4514 \\
\hline \hline ArticleDOI & $:$ & $10.1186 /$ gb-spotlight-20020627-01 \\
\hline \hline ArticleCitationID & $:$ & spotlight-20020627-01 \\
\hline \hline ArticleSequenceNumber & $:$ & 180 \\
\hline \hline ArticleCategory & $:$ & Research news \\
\hline ArticleFirstPage & $:$ & 1 \\
\hline \hline ArticleLastPage & $:$ & 2 \\
\hline \hline & & RegistrationDate : 2002-6-27 \\
\hline ArticleHistory & $:$ & OnlineDate \\
\hline \hline ArticleCopyright & $:$ & BioMed Central Ltd2002-6-27 \\
\hline \hline ArticleGrants & $:$ & \\
\hline \hline ArticleContext & $:$ & 130593311 \\
\hline \hline
\end{tabular}




\section{Jonathan B Weitzman}

Email: jonathanweitzman@hotmail.com

Schwann cells are responsible for axon myelination in the peripheral nervous system. Disabling demyelinating neuropathies are associated with mutations in genes associated with regulating the process of myelination. In the June 25 Proceedings of the National Academy of Sciences, Nagarajan et al. describe a study of gene expression in Schwann cells (Proc Natl Acad Sci USA 2001, 99:8998-9003). They performed microarray analysis on normal or injured sciatic nerve material in mice following nerve crush or transection. More than $15 \%$ of the 12,645 genes that they analysed changed expression following injury. To interpret their results they performed careful anchor gene correlation analysis (AGCA), using the expression of proliferative markers (Ki-67 antigen or PCNA), inflammatory genes ( $M C P-1$ or interleukin 6) or myelination genes (such as $P M P 22$ or $M A G$ ), as anchor genes. Their analysis led to the identification of myelination-associated genes involved in lipid synthesis and fatty acid metabolism.

\section{References}

1. Hereditary peripheral neuropathies: clinical forms, genetics, and molecular mechanisms.

2. Proceedings of the National Academy of Sciences, [http://www.pnas.org]

This PDF file was created after publication. 